Хафизова Н.А.. Женские архетипы в романе Ф.М. Достоевского «Идиот» // Вестник ПНИПУ. Культура. История. Философия. Право. - 2018. - № 4. - С. 45-56. DOI: 10.15593/perm.kipf/2018.4.05

Khafizova N.A. Female Archetypes in the Novel by F.M. Dostoevsky "Idiot". Bulletin of PNRPU. Culture. History. Philosophy. Law, 2018, no. 4, pp. 45-56. DOl: 10.15593/perm.kipf/2018.4.05

DOI: $10.15593 /$ perm.kipf/2018.4.05

УДК 124.42:82

\title{
ЖЕНСКИЕ АРХЕТИПЫ В РОМАНЕ Ф.М. ДОСТОЕВСКОГО «ИДИОТ»
}

\author{
Н.А. Хафизова
}

\author{
Пермский национальный исследовательский \\ политехнический университет, Пермь, Россия \\ ORCID: https://orcid.org/0000-0002-5937-458X
}

\begin{abstract}
Со времен выделения искусства в самостоятельную сфреру культуры оно являлось манифестацией идеи красоты - красоты земной/природной и красоты небесной/божественной. Поэтому обращение к проблемам метафизики искусства неотделимо от осмысления красоты, фрорм и способов ее явленности. Античная культура не только персонифицировала идею красоты (и сопряженную с ней идею любви) в образе богини Афродиты, но и совершила первую философскую рефлексию в отношении нее, выделив аспекты небесной (Афродита Урания) и земной (Афродита Пандемос) красоты.

История культуры показывает, что наиболее полное художественное воплощение идеи красоты находят в женских персонажах, анализ которых позволяет сгущать и придавать плотность (плоть) абстрактной идее красоты. В статье рассматриваются два основных женских образа из романа Ф.М. Достоевского «Идиот» - Настасья Филипповна и Аглая Ивановна.

Истолкование образа данных героинь, помимо непосредственно герменевтической практики прироста собственного бытия размышляющего-при-письме автора, ставит задачи применения следующих методологических приемов. Во-первых, используется методология юнгианского анализа с опорой на концепт архетипа как конкретно-образного выражения какой-либо идеи. Во-вторых, задействован диалектический метод для описания итога деструктивных отношений между архетипами (идеями) в человеческой душе.

При анализе впервые установлены важные узловые моменты смысловых пересечений между архетипами Афродиты Урании и Лилит, а также между образами Афрродиты Пандемос и Евы. Утверждается, что первая пара реализует волю-к-любви и волю-к-смерти дионисийское измерение культуры, тогда как вторая - волю-к-жизни и волю-к-власти - аполлонический модус культурного бытия.

В статье показано, что каждая из героинь романа Ф.М. Достоевского является парадоксальной художественной манифестацией той или другой архетипической пары. Парадоксальность выражается в том, что данные персонажи изначально представлены Ф.М. Достоевским не такими, какие они есть. И только по мере разворачивания повествования в Настасье Филипповне Барашковой раскрываются лики Афродиты Урании и Лилит, а в Аглае Ивановне Епанчиной - Афродиты Пандемос и Евы.

Ключевые слова: герменевтика, аналитическая психология, архетип, художественный образ, Афродита, Ева, Лилит, красота, любовь, женственность.
\end{abstract}

\section{FEMALE ARCHETYPES IN THE NOVEL BY F.M.DOSTOYEVSKY “IDIOT”}

\author{
N.A. Khafizova \\ Perm National Research Polytechnic University, Perm, Russian Federation \\ ORCID: https://orcid.org/0000-0002-5937-458X
}

\begin{abstract}
Since the isolation of art as the independent sphere of culture it was the manifestation of the idea of beauty - beauty terrestrial/natural and beauty heavenly/divine. From here, the appeal to the problems of metaphysics of art is not separable from the judgment of beauty, forms and ways of its manifestation. The ancient art not only personified the idea of beauty (and the idea of love interfaced to it) in an image of the goddess Aphrodite, but also made the first philosophical reflection concerning it, having marked out aspects heavenly (Aphrodite Urania) and terrestrial (Aphrodite Pandemos) of beauty.

History of cultural shows that female characters whose analysis allows to condense and give density (flesh) to the abstract idea of beauty contain the fullest art embodiment of the idea of beauty. In article two main female images from the novel by F.M. Dostoyevsky «Idiot» - NastasiaFilippovna and Aglaia Ivanovna are considered.

Interpretation of these heroines, besides directly hermeneutical practice of a gain of own life reflecting-at-the letter of the author, pursues itself problems of approbation of the next methodological moments. First, the methodology of the Jung's analysis with a support on an archetype concept as concrete trope of any idea is used. Secondly, the dialectic method for the description of a result of the destructive relations between archetypes (ideas) is involved in a human soul.
\end{abstract}

(c) Хафизова Наталия Алексеевна - кандидат философских наук, доцент кафедры философии и права, e-mail: khafizova1970@rambler.ru. 
In the analysis important focal points of semantic crossings between archetypes of Aphrodite Urania and Lilith and also between images of Aphrodite Pandemos and Eve's are for the first time determined. It is claimed that the first couple more realizes will-to-love and will-to-death - Dionisian measurement of culture whereas the second - will-to-live and will-to-power - an Apollonian mode of cultural life.

Article shows that each of heroines of the novel of F.M. Dostoyevsky is a paradoxical art demonstration of this or that archetypic couple. The paradoxicality is expressed that these characters are initially shown by F.M. Dostoyevsky not such what they are. And only on the course of deployment of the narration choirs of Aphrodite Urania and Lilith are reveal in NastasiaFilippovnaBarashkova, Aglaia Ivanovna Epanchina appears as Aphrodite Pandemos and Eve.

Keywords: hermeneutics, analytical psychology, archetype, artistic image, Aphrodite, Eve, Lilith, beauty, love, femininity.

Осмысление идеи красоты, форм и различных способов ее явления представляет собой важнейшую работу по постижению сущности художественного образа. Будучи ядром мифа, искусства и литературы, он воплощает красоту в диалектике прекрасного и безобразного, возвышенного и низменного, трагического и комического, поэтического и прозаического.

Сохранение метафизического плана художественного творчества напрямую связано с прорывом и присутствием в художественном произведении высказанного иного, или хотя бы намека на него. То, что культура проверила временем и отобрала в качестве классики, непременно имеет подобное наполнение.

В европейской культуре идея красоты нашла выражение и впервые была подвергнута философской рефлексии в образе богини Афродиты. Однако речь в статье пойдет не столько о ней, сколько о проявлениях ее прежде всего в женских художественных образах ${ }^{1}$.

Методологические замечания. Любое истолкование текста есть герменевтика. В данном случае, истолкование образов двух героинь из романа Достоевского - Аглаи Ивановны Епанчиной и Настасьи Филипповны Барашковой - дается не столько с целью обнаружения авторского замысла, сколько для расширения смыслового поля своего жизненного мира, для встречи с собой-иной, для «прироста бытия», как бы сказал Х.-Г. Гадамер [2, с. 188].

Истолкование двух женских персонажей романа Ф.М. Достоевского «Идиот» будет дано посредством обращения к двум культурным традициям. Во-первых, будет задействована античная традиция с ее образами Афродиты Урании и Афродиты Пандемос. А во-вторых, в связи с тем, что авторский интерес более связан с осмыслением архетипов Евы и Лилит, принадлежащих иудеохристианской культуре, образы этих двух барышень из романа будут интерпретированы сквозь призму последних тоже. Естественно, перед этим будет дан краткий анализ основ дополнительности и корреляций между Афродитами, с одной стороны, и Евой с Лилит - с другой. Тем самым будет проведена амплификация - расширение смыслового содержания образов героинь романа.

Следует также ввести еще один методологический момент: опора на теорию архетипов К.-Г. Юнга. В статье эта теория нашла свое выражение в использовании понятия «архетипа» в отношении к образам Афродиты, Евы и Лилит. Каждая из них - это персонифицированная идея, «форма без содержания», активизирующаяся и обретающая уникальное содержание в типичной или пограничной ситуациях [3, с. 18]. Архетип проявляется в поведенческих и мировоззренческих тенденциях и стратегиях.

Обращение к художественным образам как к обналиченным архетипам обусловлено тем, что, по Юнгу, «творческий процесс [...] складывается из бессознательного одухотворения архетипа, из его развертывания и пластического оформления вплоть до завершенности произведения искусства» [4, с.118-119]. Подобное видение творческого процесса предполагает, что, например, все персонажи являются манифестацией того или иного архетипа, той или иной идеи. А работа с идеями - дело философии.

Две Aфродиты. Как известно, античная культура явила богиню Афродиту во множественных версиях ее возникновения [5, с. 62-65]. Однако у Сократа, по версии Платона и Ксенофонта,

\footnotetext{
${ }^{1}$ Более подробно о непременной связи идеи красоты в культуре с женским началом можно прочесть, например, в [1].
} 
Афродита предстает в виде Афродиты Урании и Афродиты Пандемос. Так, в своем диалоге «Пир» Платон устами Павсания утверждает: «...старшая, что без матери, дочь Урана, которую мы и называем поэтому небесной, и младшая, дочь Дионы и Зевса, которую мы именуем пошлой» [6, с. 181-182]. Эта же идея повторяется и Ксенофонтом в его «Пире» [7, с. 237-240].

Каждая из них соответствует одному из Эротов: связанный с Афродитой Уранией предпочитает любовь к духу возлюбленных, второй тянется к телу и всему, что дает блага земной жизни (богатство, статус, деторождение, власть над телом другого). Отсюда Афродита Урания есть одухотворяющая сила, освобождающая дух, а Афродита Пандемос является той, что заземляет, замыкает человека на земные удовольствия, материальные и социальные блага.

Если попытаться развить эти образы двух Афродит и отразить их действие на человека, то Афродита Пандемос более воздействует на душевный строй человека, удовлетворяя потребности последнего в том, чтобы мир его телесного повседневного существования был душевно организован, чтобы человек чувствовал гармонию в себе и в своих отношениях с миром. Афродита Пандемос привязывает к повседневности, примиряет человека с фактом неизбывности последней, приукрашивает ее, что выражается в таких эстетических переживаниях, как удовольствие и наслаждение. Поэтому основное действие младшей из сестер есть гармонизащия, что часто и ассоциируется с умиротворением, со счастьем принятости и признанности.

В противовес вышеописанному Афродита Урания имеет дело с человеческим духом, формула которого, по меткому выражению актрисы Аллы Демидовой, проста: «иди туда, не знаю куда, найди то, не знаю что», - ибо он дарует ощущение мерцающей, являющейся и ускользающей истины бытия. Поэтому встреча с нею переживается как потрясение, самообновление (вплоть до катарсиса), благодаря которым не только не происходит умиротворения и примирения с этой повседневностью, но наоборот: дух возмущается, активизируется, вырывается из сетей обыденной повседневности, устремляется к неведомому, открывая мощь здесьбытия. Она завораживает и вдохновляет.

Платоновская интерпретация происхождения Афродиты Урании от капель крови Урана, упавших в морскую пену при его оскоплении, утверждает в ней силу и недосягаемую для женщин высоту мужской культуры, приоритет духа перед телом, отсюда приоритетность гомосексуальной, а не гетеросексуальной любви. Однако Афродита - женское божество и, думается, на сей мифологический сюжет стоит взглянуть по-иному.

Несмотря на то, что Афродита Урания произошла только от мужского начала, ее рождение можно считать символическим выражением, с одной стороны, предельной (от)падшести мужского начала в изначальную женскую стихию - море, а с другой стороны, его же символическим самоотрицанием в лице дошедшего до предела в своей воле к власти Урана. Оскопление Урана (потеря им своего мужского «достоинства») - это бытие-при-обнулении мужского начала и бытие-обналичивание, высвобождение в мир потенциально существовавшего до этого чистого женского начала.

Именно поэтому уместно говорить, что Афродита Урания - это не сияние мужского духа, скорее она - символ Анимы ${ }^{2}$, бытующей в глубинах мужского бессознательного. Афродита Урания и есть сама женственность в своей чистоте, незамутненности, в которой тело не противостоит духу (в отличие от Афродиты Пандемос), но продолжает его ${ }^{3}$. С другой стороны, упавшие в море капли крови «мужского достоинства» - это символ Анимуса, который и актуализирует в женщине собственную женственность, сепарируя ее от матери (морской пучины). С третьей - вызвана

\footnotetext{
${ }^{2}$ По К.-Г. Юнгу, Анима - это вечный образ женщины в мужской душе, отношения с которым и проекции которого определяют опыт, касающийся реальных женщин [8, с.26-29]. Мужской архетип в женской душе получил название Анимуса.

${ }^{3}$ У В.В. Розанова в «Уединенном» есть похожая идея: так, он говорит, что пол - это дух, особым образом расположившийся в теле [9].
} 
она к жизни действиями бога Кроноса (времени $)^{4}$. Дело в том, что, например, Гея, Гера и Афродита Пандемос - это разные ипостаси Великой Матери (по Платону, именно Пандемос покровительствует деторождению), которая более символизирует изначальное пространство (утроба) - до времени, до рождения. Если говорить об Афродите Урании, то она более ассоциируется с временем, с временными структурами сознания. Женственность есть воля-к-любви, есть временение себя и мира в любви - до смерти и перерождения ${ }^{5}$.

Интересно, что египетская богиня Нуит изображается в виде звездного неба: и не понятно, указывает ли это на то, что она - богиня небесного пространства, или что она - богиня Небесная, подобно Афродите Урании. Думается, что Нуит - богиня, поглощающая и рождающая солнце и звезды, не столько символ Великой Матери, сколько символ ритмизации, временения земного бытия небесами ${ }^{6}$.

Вечная женственность потому вечная, что она - и источник времени, и она же - проводник в преодоление времени. Так, В.С. Соловьев в своем учении о Софии как вечной женственности и Премудрости Божьей воспроизводит взгляд гностиков на то, что именно София ответственна за отпадение мира от Бога и за начало временения мира, однако только через нее и возможно новое воссоединение с Плеромой [11]. Время связано со смыслом его производством, изменением и созерцанием «вечных истин» (София), а пространство с производством символов, ибо, как бы сказал М. Хайдеггер, вещи/символы и создают пространство, его структуру [12, с. 318-320].

Eва и Лилит. Афродита Урания и Афродита Пандемос - две стороны одной медали под названием «красота», так же как Ева и Лилит - две стороны одной медали под названием «женскость» - той или иной практики женского бытования.

Образы Евы и Лилит стали итогом многовекового процесса осознания женщины в разных ее проявлениях. Изначально в шумерской культуре единая богиня сочетала в себе все [13, с. 9]. Развитие патриархата с его желанием установить контроль над женской сексуальностью как над чем-то в принципе неподвластным мужчине расщепило единый образ богини, явив множество женских божеств. Самое радикальное разделение связано с проекцией богинь на женские человеческие образы, возникшие в иудейско-христианской культуре - Евы и Лилит.

Культурные и социальные практики, возникшие в патриархальной культуре и действующие до сих пор, поддерживают эту расщепленность женской души. Отныне всякой женщине самой приходится собирать себя, целить (делать целой), интегрируя одну из них в свой лидирующий архетип.

Параллели между двумя Афродитами, с одной стороны, и с Евой и Лилит - с другой, напрашиваются сами. Афродита Пандемос рождена от мужского и женского начала, она не есть чистая женственность сама по себе, так же как и Ева. Последняя несет в себе дух Ветхого Адама, ибо создана из его кости, чем наряду с волей-к-жизни наследует мужскую жизненную стратегию - волю-к-власти, самоутверждение, разделение, разграничение. А вот Лилит, как и Афродита Урания, по праву может считаться самодостаточным женским началом, реализующим волю-к-любви (слияние) и волю-к-смерти (преображение).

\footnotetext{
${ }^{4}$ Кронос - бог земледелия, изначально пожирающий детей своих (аналог будущего римского Сатурна), ассоциируется со смертью. Думается, неслучайно в поздней античности это воля-к-смерти стала ассоциироваться с временем.

${ }^{5}$ Активность пространственных или временных структур сознания является важным маркером для идентификации того или иного типа женскости, ибо Великая Мать символически более связана с мужским началом, чьи пространственные структуры также активны [10].

${ }^{6}$ Кстати, в колоде карт Таро Тота эта богиня изображена на карте «Эон», символизирующей конец времени, даже - саму смерть, но ведь время и есть бытие-к-смерти, ибо временность всегда есть преходящесть. А вот египетская богиня Баст, изображающаяся с головой кошки и которая может быть ласковой, как кошка, и яростной, как львица, будучи сестрой Нуит, вполне выражает архетип Великой Матери, заботящейся о произведенных детях, сохраняя семейный очаг.
} 
Понятно, что Афродиту Уранию и Лилит, так же как Афродиту Пандемос и Еву, нельзя полностью отождествлять. Так, Лилит вполне соотносима не только со старшей Афродитой, но и с Афиной (Софией), а Ева - еще и с Герой; что уж говорить о множестве других персонажей греческого мифа (типа фурий, нимф, мойр), черты которых только еще ярче позволяют увидеть разнообразие узоров отношений между Евой и Лилит в женской душе. Однако Ева и Лилит, думается, являются также разным воплощением идей красоты и любви, поэтому вполне обоснованно Афродиту Уранию можно ассоциировать с Лилит, чистой женственностью, а Афродиту Пандемос - с Евой, архетипом Великой Матери.

Стоит хотя бы в порядке упоминания (для обоснования этого нужна отдельная статья) ввести еще одно важное различие между парами Лилит-Афродита Урания и Ева-Афродита Пандемос. Основываясь на идее Ф. Ницше, можно утверждать, что первая пара более реализует дионисийское начало, вторая - аполлоническое [14].

Идеальная (чистая) модель всегда ущербна по сравнению с жизнью, ибо в ней выхолощена возможность иного. В реальности данные архетипы - две стороны женской души, вступающие в определенные отношения, которые могут быть гармоничными и дисгармоничными. Первый вариант появляется в итоге интеграции одной стороны другой, когда основной архетип тем ярче и полнее раскрывается, чем ярче и полнее фон. При втором варианте ипостаси не интегрированы, поэтому базовый - с детства актуализированный - архетип инфантилен, а другой спонтанно дает о себе знать в силу слабости первого ${ }^{7}$.

Если говорить о Настасье Филипповне и Аглае Ивановне, то сразу следует признать, что они представляют собой наиболее чистые модели, не интегрировавшие свое иное. Поэтому их повседневные проявления будут более соответствовать инфантильности Евы и Лилит, тогда как базовые установки очень хорошо будут видны сквозь призму двух Афродит. Ниже, для описания специфики этих женских персонажей, будут даны основные характеристики именно инфантильных образов Евы и Лилит.

Инфантильная Лилит - та, которая не интегрировала Еву, а значит, не освоила или подавляет Анимус. Характерными чертами данного состояния Лилит можно назвать следующие:

1. Эгоцентризм до полного произвола - «хочу и все!». Ей нет дела до реальных желаний любимых, ибо она живет своими идеализациями. При этом от обожествления кого-либо до его же демонизации с ее стороны - один шаг.

2. Она не знает границ ни в любви, ни в ее отсутствии в силу неразвитости чувства самоуважения (собственное достоинство - это черта Евы). Лилит не нужны внешние границы, ведь она - внутренняя женщина, да и любовь в своем пределе стремится к слиянию. Ее реакции - мгновенны при защите любимых или себя: ярость и месть. Ярким примером можно считать Маргариту: «Я стала ведьмой от горя и бедствий, поразивших меня!». Ее ведьмовство не сущностно, а реактивно.

3. Опасность обожествления ничтожества (как проекция недостаточно выраженной самоценности).

4. Ревность Лилит - глубинная, она возникает в ситуации невозможности реализовывать свою сущность - служить мужчине, любить его. Здесь ревность есть выражение не чувства собственности, но страха собственной ненужности в качестве любящей. Ее ревность реализует эгоцентризм: я - та, что создана для него ${ }^{8}$. Преодоление ревности связано с нахождением формы приемлемого для себя служения любимому даже в состоянии покинутости им.

\footnotetext{
${ }^{7}$ Инфантильность - это всегда итог отсутствия интеграции с противоположным иным, что производит личностную нецелостность. Интеграция позволяет каждому из начал выступить в зрелом виде, избегая своих крайностей.

${ }^{8}$ В этом смысле женский эгоизм «мыслит» так: он - тот, кто мне непременно нужен.
} 
5. Основные крайности: она - или ужасная мать (потому что либо не до детей, либо дети лишь приложение любви к мужчине 9 ), или «снежная королева» (асексуальность при служении идее, а также при невозможности переживать мужчину в качестве бога).

Инфантильность Лилит в ситуации стресса, депрессии приводит к неконтролируемым проявлениям архетипа Евы.

А теперь проговорим черты инфантильной Eвы - поведенческой женской модели, не интегрировавшей Лилит:

1. Страсть к самоутверждению во что бы то ни стало, соперничество. Даже порядок и забота о своем внешнем виде есть не проявление тяги к гармонии, красоте, а именно к переделыванию мира под себя, к соблазнению как форме власти, в которой дает о себе знать воля к жизни.

2. Истеричность и категоричность из-за обостренного чувства собственного достоинства, которое при нечувствовании самодостаточной самоценности (что есть у зрелой Лилит) оборачивается защитой своих интересов в виде истерики, скандальности и категоричности. Часто грубовата в общении, скупа на эмпатическую эмоциональность.

3. Болезненная ревность, неприятие и непрощение измен, ибо она воспринимает любимых в качестве собственности (любимые - те, в ком я нуждаюсь) и точки приложения своей сексуальности. Она желает только одного - контроля над мужчиной для удержания его подле себя. Ревность Евы - в том числе - может подпитываться страхом быть оставленной одной с детьми, страхом за благополучие детей. Преодоление ревности возможно через развитие своей самостоятельности. Ее ревность коммуникативна по источнику возникновения.

4. Она реализует не столько любовь к мужчине, сколько свое желание быть/стать для него единственным центром. Даже сексуальные отношения, будучи важными для нее сами по себе, могут стать способом реализации тактики быть незаменимой для него в чем-то, чтобы привязать мужчину к себе. Иногда жажда самоутверждения выливается в героизм мученичества ${ }^{10}$.

5. Часто, будучи кость от кости Адама, она наследует фанатичную страсть к пространству, в котором ей, однако, не столько вещи важны, сколько - чистота и порядок ${ }^{11}$.

6. Основные крайности: Ева может стать ужасной матерью - душить опекой в силу женской нереализованности; объектом ее чувственности в этом случае становится ребенок, без которого она вообще не чувствует себя живущей. Так же инфантильность может провоцировать сексуальную ненасытность, чрезмерность (ибо она - сама телесность, чувственность), «бешенство матки» (истерию) как жажду власти через секс.

Таким образом, диалектика двух Афродит, увиденная и осмысленная изначально миром мужской культуры, получает свое дальнейшее разворачивание и наполнение в диалектике двух архетипов - Лилит и Евы.

Аглая Ивановна и Настасья Филипповна. Данный анализ есть иллюстрация связи двух Афродит и двух типов женскости, взращенных иудео-христианской культурой. Ф.М. Достоевский в романе «Идиот» виртуозно изобразил «диалектику» жизни на примере двух героинь этого романа Аглаи Ивановны Епанчиной и Настасьи Филипповны Барашковой ${ }^{12}$.

\footnotetext{
${ }^{9}$ В качестве инфантильной Лилит показателен образ волшебницы Медеи, которая, будучи преданной Ясоном, уничтожила своих детей.

10 Например, способность жить в демонстрируемом всем страдании с алкоголиком, наркоманом, садистом, мужчинойребенком по принципу «это - мой крест, и нести его мне!».

${ }^{11}$ Симона де Бовуар подобную увлеченность домашним уютом замечательно описывает на страницах своего «Второго пола» $[15$, с. 498-504].

${ }^{12}$ К слову, если проанализировать классические произведения хотя бы русской литературы, то можно обнаружить два данных женских типажа почти повсюду. Например, у И.А. Гончарова в «Обломове» это - Ольга Сергеевна Ильинская и Агафья Матвеевна Пшеницына, у Л.Н. Толстого в «Анне Карениной» - Анна Каренина и Долли Облонская.
} 
Каждая из них олицетворяет только одну из Афродит, однако с самого начала не очень понятно, какой из них соответствует каждая из героинь. И первое впечатление обманчиво: правильная Аглая Ивановна - как будто Афродита Урания, а с сомнительным прошлым Настасья Филипповна - Афродита Пандемос. Действительно, в начале романа Аглая Ивановна кажется Афродитой Уранией (Лилит) с ее отстраненностью, даже некоторой сексуальной холодностью, так же как и Настасья Филипповна более видится Афродитой Пандемос (Евой) во всей полноте жизненного порыва, страсти, кажущегося наслаждения своею властью над множественной свитой мужчин. Однако по ходу романа все оказывается с точностью до наоборот ${ }^{13}$.

Если задуматься, то чистая (небесная) красота - самодостаточна, тогда как земная нуждается в зрителях и поклонении. Именно поэтому первая не чурается запачкаться, ибо ничто не может ее опошлить. Обратившись к образу Аглаи Ивановны, можно без труда разглядеть, что та вечно держится за свою чистоту, ибо знает, что потерять ее может в один миг. Она влюблена в чистоту и красоту, ценит и готова их отстаивать. Настасья Филипповна, в свою очередь, и есть сама флуктуирующая красота: она в ней живет. Вот и князь Мышкин восхищается тем в ней, что она из ада чистой вышла: на это способна только та, на ком печать Афродиты Урании.

Это напоминает то, как пушкинский Моцарт способен на музыкальное баловство, тогда как Сальери оскорблен унижением музыки: возвышенный Моцарт не может потерять чувства красоты, тогда как восхищающийся, влюбленный в музыку Сальери боится утерять ее. Возвышенный способен удерживать образ красоты неизменным (великое делание есть удержание, наподобие того, как действует аристотелевский бог, удерживая мир мыслью), тогда как восхищающийся должен делать бесконечные усилия по его сохранению в себе в неизменном виде и в дотягивании внешнего мира до красоты ${ }^{14}$.

Афродита Урания и Лилит избыточны и самодостаточны, Афродита Пандемос и Ева переживают нехватку, ибо, чтобы оставаться Пандемос, им нужно привлекать к себе внимание. Рассмотрим эти проявления подробнее на примере обозначенных героинь Федора Михайловича.

Настасья Филипповна Барашкова. Настасья Филипповна (далее - Н.Ф.) появляется в романе в ауре разговоров о ней как о падшей женщине: содержанка Тоцкого, многочисленные домыслы о связи с ухажерами, приняла дорогой подарок от Рогожина - все это, кажется, не оставляет сомнений в том, что в ее лице мы имеем дело с Афродитой пошлой, с Евой. Однако если приглядеться, то все совсем не так. Не по своей воле она стала содержанкой, и с Лихачевым жить не стала, хотя он и сулил ей денег. И с подарком Рогожина легко распрощалась: что деньги, когда она перспективы смысловой (временной то есть!) для себя не видит. И жизненные страдания научилась скрывать, сохраняя свое достоинство.

Князь Мышкин, увидев портрет Н.Ф., говорит о том, как удивительно она хороша, замечая страдание в ее глазах при веселом лице. Что это - как не чувствование своего «самостояния», несмотря ни на что? И далее князь вопрошает: «...добра ли она? Ах, как бы добра! Все было бы спасено!» ${ }^{15}$. Данное вопрошание является очень важным ключиком к идентификации Н.Ф., ибо чистая красота находится «по ту сторону добра и зла», она не утилитарна, но онтологична и всегда ускользающа и неопределенна, как истина о бытии.

Князь Мышкин, вновь увидев ее портрет, еще раз фиксирует противоречивую (единство гордости, презрения, доверчивости и простодушия), ослепляющую, невыносимую красоту бледного лица и горящих глаз Н.Ф. Очарованный ее страданием и красотой - ее возвышенностью, - он решается даже поцеловать ее портрет.

\footnotetext{
${ }^{13}$ Может быть, это проявление общей специфики женского бытования - быть тайной даже для себя?.. Как знать.

14 Развивая сократовскую мысль из «Федра», можно сказать, что влюбленный одержим, серьезен, негибок, хотя его легко сломать. Живущий в возвышенном и в красоте легок, смешлив и эластичен, но при этом прочен, ибо укоренен в красоте [16, с. 237-241].

${ }^{15}$ Здесь и далее цит. по: Достоевский Ф.М. Идиот / Собр. соч.: в 12 т. Т. 6-7. - М.: Правда, 1982.
} 
Думается, что в лице Н.Ф. читатель реально зрит Афродиту Уранию как идею чистой красоты, однако Лилит в ней предстает в инфантильном варианте. Именно поэтому время от времени в Н.Ф. совершенно спонтанно прорывается ипостась Евы, и именно поэтому она погибает, ибо жизнь не терпит скудности идеала.

Да и фамилию для этого автор подобрал подходящую - Барашкова. И ее уменьшительноласкательное звучание кажется неслучайным. Н.Ф. стала этаким барашком (ягненком, агнцем), принесенным в жертву, заколотым Парфеном Рогожиным - человеком с «больной страстью» почти что религиозного фанатика ${ }^{16}$, ибо Афродита Урания невыносима сама по себе.

Интересно, что когда Н.Ф. приехала в Петербург к Тоцкому, он обнаружил в ней перемену, спровоцированную слухом о его женитьбе. Скорее это была не перемена, а - первое явление Н.Ф. во всей полноте образа Лилит. Ее описание говорит само за себя: начитанная, умная, с ядовитым сарказмом (отсылка к змее, чей образ потом всплывет, когда Н.Ф. в ответ на предложение выдать ее замуж выкажет свое расположение бывшему своему благодетелю). Глубокий мрак во взгляде и еще более украсившая ее бледность (у Евы была бы полнокровность).

Женщина-тайна: она красива, и больше ничего о ней неизвестно. Все эти характеристики говорят о том, что перед читателем в образе Н.Ф. предстала Лилит. Князь Мышкин позже обнаружит в себе восприятие ее красоты как ужасной: от красоты Аглаи просто боязно, здесь же - экзистенциальный ужас, ощущение, что, глядя в глаза Н.Ф., встречаешься с парализующей бездной. Такую красоту невозможно любить земной любовью, особенно если ты болен и не можешь полностью владеть собой, поэтому остается либо ужасаться ее мощи, либо - жалеть.

Итак, основные черты Лилит в Н.Ф.:

1. Она не против роскоши, которая ей приятна, но свободна от нее в силу самоценности и самодостаточности (любовь же к богатству - это черта Евы, наследие Адамовой воли-квласти). Сцена, в которой Н.Ф. отказывается от 75 тысяч, от жемчуга, от 100 тысяч Рогожина, показательна в этом плане.

2. Живет из принципа «Как хочу я!» Так, князь Мышкин говорит о ней: «Остановить ее нет никакой возможности, если она убеждена в своей цели» (2 часть, 11 глава). Он постоянно твердит о Н.Ф., что она - сумасшедшая и помешанная. Н.Ф. ведет себя максимально эгоцентрично, не вписываясь в рамки нормальности, однако что есть норма, как недоговоренность по поводу необходимого и достаточного уровня реализации идеала. Однако любой идеал ограничен, ибо он есть граница земного воплощения идеи, тогда как последняя не может полностью пребывать в нем. Именно поэтому встреча с чистой идеей чего-либо (в данном случае, идеей красоты) воспринимается как нечто из ряда вон выходящее, как ненормальное, как необъяснимое с позиции земных представлений о правильном и должном, как сумасшествие. Князь Мышкин так и говорит, что «не может ее лица вынести», ее красоты, которая должна спасать, а она убивает его (часть 4 , глава 9).

3. Н.Ф. демонстрирует страсть к разоблачению как проявление воли-к-истине (например, в сцене, где Н.Ф. активно поддерживает предложение Фердыщенко, чтобы гости рассказали о самом мерзком своем поступке). Такова женственность: в ее зеркале каждый есть тот, кто он есть. Она собой отражает другого: данное свойство Н.Ф. подчеркнул Парфен Рогожин, говоря князю Мышкину, что с тем она будет не такая, как с ним.

4. Гордость не от самолюбия, а от переживания самодостаточности, ибо самоценности как раз Н.Ф. и недостает. Князь Мышкин угадал в Н.Ф. то, что она хоть в прачки пойдет, но с Рого-

\footnotetext{
${ }^{16}$ Вообще, Федор Михайлович ведет тончайшую игру с именами персонажей. Так, фамилия Рогожин отсылает к рогоже, ассоциирующейся с аскетизмом, в основе которого часто лежит агрессия в отношении себя, неусмиренная гордыня. Мышкин же, наоборот, символ смиренной гордыни, он живет тише мыши, любит ослов, например, что отсылает читателя к Христу, въехавшему в Иерусалим на осле как символе мира.
} 
жиным не останется, ибо для женщин типа Лилит важно мужчину переживать в качестве бога. Вот и в письмах к Аглае Ивановне (3 часть, 10 глава) она пишет о своей неспособности к самоунижению не из припадка гордости, не из чистоты своего сердца. Ганя как-то говорит о Н.Ф.: «Вот этакие-то и любят властвовать!», однако в том-то и дело, что ее власть идет не оттого, что у нее есть такая цель, а потому что так получается в силу харизмы ее женственности.

5. Князь Мышкин для нее - бог, с которым она не может быть ввиду чувствования своего несовершенства; она, прошедшая жизненный ад, боится его опозорить своим сомнительным прошлым, ибо для Лилит самое главное - возвышенно служить любимому. Проблема Лилит - временная потеря самоценности в глазах мужчины-бога, а не самолюбия, как у Евы. В этом смысле Н.Ф. - инфантильная Лилит, «нешлифованный алмаз», как говорит о ней Тоцкий. Отсюда яростность Н.Ф. - естественная ярость «дикой женщины».

В силу того что Н.Ф. представляет собой инфантильную Лилит, время от времени в ней прорывается Ева. При первой встрече с князем Мышкиным (в прихожей) и потом (при общении с семьей Гаврилы Ардалионыча) она повела себя, с одной стороны, своенравно/эгоцентристски, как Лилит, но с другой стороны, высокомерно-агрессивно: шла инициативно защищать себя, а не с целью оскорбить или унизить.

Также в Н.Ф. из-за слабости переживания собственной самоценности любовь-служение к князю Мышкину в итоге выстрелила материнской - желанием видеть его счастливым (пусть даже и с другой), ибо суть материнской любви «отпустить» [17] $]^{17}$.

Если говорить о Парфене Рогожине, то он относится к архетипу ветхого Адама, которому чистая красота невыносима, ибо - неподконтрольна. Именно поэтому Н.Ф. была обречена на гибель от руки Рогожина, который принес материальное воплощение красоты в жертву идее чистой красоты так же, как это сделал толстовский Позднышев. Сама по себе красота невыносима еще и потому, что обещает не уют или защищенность, как в материнской утробе, но разоблачение и бесконечную борьбу с собой.

Аглая Ивановна Епанчина. Аглая - так звали одну из граций, сопровождающих Венеру/Афродиту, и ее имя означает «сияющая». В одном из первых описаний Аглаи Ф.М. Достоевский говорит, что она была красива, начитанна, и сестры ее считали, что ей предназначена судьба земного рая (с совершенным и богатым мужем). Вполне себе образ Афродиты Пандемос и Евы, способных заземлиться в своем уюте и заземлить рядом с собой других.

Князь Мышкин охарактеризовал Аглаю Ивановну (дальше - А.И.) как чрезвычайную красавицу, на которую даже смотреть боязно и описать ее невозможно, ибо красота - загадка. Однако далее он говорит, что она - почти так же хороша, как и Н.Ф. «Почти», произнесенное в таком соотнесении двух дев, говорит о том, что красота Н.Ф. - не только другая, но и совершеннее. «В вас все совершенство», - говорит он Н.Ф.

А теперь - основные проявления Евы в А.И:

1. А.И демонстрирует свою неспособность быть в собственной женственности. Так, вместо реализации последней она часто демонстрирует капризность ребенка. Более того, она воспроизводит женственность своей матери, искренне радуясь при этом своей поведенческой похожести на мать (часть 3, глава 8).

2. В ее поведении более проговаривается женщина-мать. Например, А.И. с самого начала относится к князю Мышкину по-матерински: оценивает, воспитывает, учит его быть гордым, держится с ним строго, пытается быть другом (например, играет роль связного между

17 Хотя, может, следует признать, что подобное отношение и есть вершина женского служения идее любви, или это эгоцентрический способ вернуться к себе из невозможности реально быть с любимым. 
Н.Ф. и князем). Да и сам князь воспринимает ее как свет земной - спасающий, убаюкивающий, выслушивающий: точно материнский. А.И. для него - свет и тепло, в которые можно ускользнуть и спрятаться от духовного напряжения, вызываемого красотой Н.Ф. Очень показательна характеристика любви А.И. Евгением Павловичем Радомским: «Аглая Ивановна любила как женщина, как человек, а не как... отвлеченный дух» (часть 4, глава 9).

3. Отвечая на предложение Гаврилы Ардалионовича, А.И. сказала, что готова была стать тому другом, и князю Мышкину она предложила то же самое. Ева для мужчины - тыл, друг, мать его детей, тогда как Лилит - вечная возлюбленная, муза.

4. Развитое чувство собственного достоинства до гордыни, презирающей тех, кто видится ей недостойными. «Девка самовластная, сумасшедшая, избалованная, - полюбит, так непременно бранить вслух будет и в глаза издеваться», - такую дала ей характеристику ее мать. А на знаменитой встрече «четырех» (часть 4, глава 8), описывая отношения между А.И. и Н.Ф., Ф.М. Достоевский говорит: «Одна из этих женщин до того уже презирала в это мгновение другую и до того желала ей это высказать..., что, как ни фантастична была эта другая, со своим расстроенным умом и больною душой, никакая заранее предвзятая идея не устояла бы, казалось, против ядовитого, чисто женского презрения ее соперницы». Вот они - такие разные модели женскости: женственность Н.Ф. и «бабство» А.И.

5. Жажда внимания, самоутверждения. Так, в 13-летнем возрасте А.И. подумывала о самоубийстве, чтобы все о ней говорили (часть 3, глава 8). Она пытается произвести впечатление, а не быть собой. Особенно показательна сцена, где она читает стихотворение о «Бедном рыцаре».

6. Кстати, здесь же А.И. продемонстрировала свое отношение к чистой идее и красоте: насмешка и над красотой, и над служением ей. А.И. достаточно рациональна, разумна и пытается своей эксцентричностью проявить границы нормальности для тех, кто игнорирует их, девальвируя ценность существующего идеала (идеал для нее важнее идеи).

7. Истеричность: не гневливость, не яростность, а именно истеричность как бессилие женственности (часть 3, глава 1). Гневливость же, если и есть, то из защиты от унижения.

Продолжая сравнение этих женщин, можно констатировать, например, что Аглая Ивановна, как манифестация Афродиты Пандемос, страдает из самолюбия, из величественного образа собственной жертвы, из не-признанности ее страдания, тогда как Н.Ф. - в образе Афродиты Урании страдает из-за падшего в пошлость мира. Причем страдание последней скрыто от глаз мира. Ева часто пестует страдания как самоцель (геройствует напоказ), для Лилит страдания - вынужденный пошлый образ жизни, который ей не хотелось бы демонстрировать.

Н.Ф. - это Афродита Урания, потерявшая крылья в пошлости земной жизни и потому обессиленная. Страдания Н.Ф. по поводу своей падшести есть доказательство ее тоски по себе небесной. Она, и правда, не может не страдать, ибо у нее нет опыта достойного (Ева ею не интегрирована) перенесения своей красоты в земной жизни, она сама не может ее вынести и потому зациклена на своем страдании. Именно поэтому Н.Ф. делает усилия не по сохранению красоты (ибо та сущностна ей), а только по нахождению в своем страдании из невозможности быть-в-красоте полноценно и полнокровно.

Князь Мышкин любит их обеих: одну как чистую красоту, которую надо спасать как женщину, полюбившую в ответ на узрение им ее природы, другую - как женщину-друга, также полюбившую его. Однако Н.Ф. и он любят друг друга как мужчина и женщина, отношения же А.И. и князя - более отношения брата и сестры, сына и матери.

Вообще, князь Мышкин, будучи идиотом (так и подмывает сказать, что князь Мышкин воплотил собой архетип дурака как меон, как возможности всего), стал для каждой из них своеоб- 
разным зеркалом, проявив собой их природу. В какой-то момент он устал гнаться за тенью Афродиты Урании в лице Н.Ф. и выбрал А.И., снизив любовный накал к Н.Ф. до жалости к ее униженному, опошленному Рогожиным и опасному положению. Афродита Урания в этом пошлом падшем мире может только страдать: и если князь не способен спасти, то исход предрешен - смерть.

В романе князь Мышкин оказался между Настасьей Филипповной (Лилит) и Аглаей Ивановной (Евой), так же как и Н.Ф. оказалась между князем (Новым Адамом, Эротом Небесным) и купцом Рогожиным (Ветхим Адамом, Эротом Пошлым), первого из которых она боготворит ${ }^{18}$, второго - ненавидит.

Подводя итог, можно сказать, что Настасья Филипповна - это чистая воля-к-любви в ее мощи и с ее изнанкой - волей-к-смерти (дионисийское начало), и выдержать подобное не всякому смертному под силу. Аглая Ивановна - это воля-к-власти, явившая себя в верхнем регистре покровительницы, однако не удержавшейся и падшей в страсть подчинять, подавлять, воспитывать, страстно встраивать в свой порядок вещей (аполлоническое начало).

Две Афродиты - это символическое выражение двух полюсов красоты, как Ева и Лилит двух типов женскости, которым следует быть со-пряженными, а не разъединенными, как это случается в гениальных художественных произведениях, в которых автор интуитивно схватывает чистые идеи, облекая их в материю образов. В реальности же необходимо сопряжение при всей их противоположности, что производит дополняющие друг друга эффекты, инициируя процесс вымещения и замещения одной другой. То, что достигло полноты, завершается, выплескивается, и то, что было малым, стремясь к своей полноте, заполняет и замещает. Полнота чего-либо - всегда обещает излет, это - бытие-при-обнулении, ибо край предела достигнут, и за ним - иное. Так устроена жизнь с ее неистовостью и бесконечной игрой противоположностей: максимальное напряжение сменяется ослаблением, которым непременно пользуется иное, определяя вектор дальнейших изменений. Переживание созданных и создаваемых художественных образов позволяет схватывать идею «золотой середины», дабы идея красоты длила себя в бесконечно меняющихся идеалах.

\section{Список литературы}

1. Хафизова Н.А. Ценностное измерение культуры повседневности // Интегративная перспектива в гуманитарных науках. - 2018. - № 1. - С. 77-89.

2. Гадамер Х.-Г. Истина и метод. - М.: Прогресс, 1988. - 704 с.

3. Юнг К.-Г. Понятие коллективного бессознательного // Структуры психики и архетипы. - М.: Академический проект, 2007. - С. 12-21.

4. Юнг К.-Г. Феномен духа в искусстве и науке. - М.: Ренессанс, 1992. - 320 с.

5. Замаровский В. Боги и герои античных сказаний. - М.: Республика, 1994. -400 с.

6. Платон. Пир // Платон. Собр. соч.: в 4 т. - М.: Мысль, 1993. - Т. 2. - 539 с.

7. Ксенофонт. Пир // Ксенофонт. Сократические сочинения. - СПб: Комплект, 1993. $416 \mathrm{c}$.

8. Юнг К.-Г. Об архетипе, особенно о понятии «Анима» // Структуры психики и архетипы. - М.: Академический проект, 2007. - С.24-43.

9. Розанов В.В. Уединенное. - М.: Политиздат, 1990. - 316 с.

${ }^{18}$ Кстати, любое боготворение кого-то своего пола, по юнгианству, - это проекция своей самости. Письма Н.Ф, которые та писала А.И., показывают, что она в той видела именно Афродиту Уранию, Лилит: так она проговаривала свою Самость, самою себя. Ведь если сравнить написанное с тем, как в реальности вела себя А.И., можно заметить абсолютное несовпадение. 
10. Хафизова Н.А. Гендерные особенности пространственно-временного бытования // Культура и искусство. - 2017. - № 5. - С. 54-67.

11. Козырев А.П. Парадоксы незавершенного трактата [Электронный ресурс]. - URL: http://krotov.info/history/19/1870/1878kozy.html (дата обращения: 10.08.2018).

12. Хайдеггер М. Вещь // Хайдеггер М. Время и бытие. - М.: Республика, 1993. C. 316-326.

13. Куоллз-Корбетт Н. Святая проститутка. - М.: Класс, 2013. - 208 с.

14. Ницше Ф. Рождение трагедии из духа музыки. - М.: Азбука, 2012. - 208 с.

15. Бовуар С. де. Второй пол. - Т. 1 и 2. - М.: Прогресс; СПб.: Алетейя, 1997. - 832 с.

16. Платон. Федр // Платон. Собр. соч.: в 4 т. - М.: Мысль, 1993. - Т. 2. - 539 с.

17. Фромм Э. Искусство любить. - М.: АСТ, 2018. - 256 с.

\section{References}

1. Khafizova N.A. Tsennostnoe izmerenie kul'tury povsednevnosti [The value dimension of everyday culture]. Integrativnaia perspektive $v$ gumanitarnykh naukakh, 2018, no 1, pp. 77-89.

2. Gadamer H.-G. Istina i metod [Truth and method]. Moscow, Progress, 1988, 704 p.

3. lung K.-G. Poniatie kollektivnogo bessoznatel'nogo [Struktury psikhiki i arkhetipy]. Moscow, Akademicheskii proekt, 2007, pp. 12-21.

4. lung K.-G. Fenomen dukha $v$ iskusstve i nauke [The phenomenon of the spirit in art and science]. Moscow, Renessans, $1992,320 \mathrm{p}$.

5. Zamarovskii V. Bogi i geroi antichnykh skazanii [Gods and heroes of ancient tales]. Moscow, Respublika, 1994, $400 \mathrm{p}$.

6. Platon. Pir [Feast]. Sobranie sochinenii v 4 tomakh. Vol. 2. Moscow, Mysl', 1993, 539 p.

7. Ksenofont. Pir [Feast]. Sokraticheskie sochineniia. Saint Petersburg, Komplekt, 1993, 416 p.

8. lung K.-G. Ob archetype, osobenno o poniatii «Anima» [On the archetype, especially on the concept of "Anima"]. Struktury psikhiki i arkhetipy. Moscow, Akademicheskii proekt, 2007, pp. 24-43.

9. Rozanov V.V. Uedinennoe [Lonely]. Moscow, Politizdat, 1990, 316 p.

10. Khafizova N.A. Gendernye osobennosti prostranstvenno-vremennogo bytovaniia [Gender features of spatial and temporal existence]. Kul'tura $i$ iskusstvo, 2017, no 5, pp. 54-67.

11. Kozyrev A.P. Paradoksy nezavershennogo [Paradoxes of the unfinished treatise], available at: http://krotov.info/history/ 19/1870/1878kozy.html (accessed 10 August 2018)

12. Heidegger M. Veshch [Thing]. Heidegger M. Vremia i bytie. Moscow, Respublika, 1993, pp. 316-326.

13. Kuollz-Korbett N. Sviataia prostitutka [Holy prostitute]. Moscow, Klass, 2013, 208 p.

14. Nitsshe F. Rozhdenie tragedii iz dukha muzyki [The birth of tragedy from the spirit of music]. Moscow, Azbuka, 2012, $208 \mathrm{p}$.

15. Bovuar de S. Vtoroi pol. Tom 1,2. [The second sex. Vol. 1, 2.]. Moscow, Progress; Saint Petersburg, Aleteiia, $1997,832 p$.

16. Platon. Fedr [Fedr]. sochinenii v 4 tomakh. Vol. 2. Moscow, Mysl', 1993, 539 p.

17. Fromm E. Iskusstvo liubit' [Art to love]. Moscow, AST, 2018, 256 p.

Получено: 10.09.2018

Принято к печати: 20.10.2018 